\title{
CORRELATION OF SNACKING FREQUENCY, HEMOGLOBIN LEVELS, PHYSICAL ACTIVITY AND POCKET MONEY WITH NUTRITIONAL STATUS IN FEMALE ADOLESCENTS
}

\author{
Dinar Putri Rahmawati ${ }^{1 *}$, Dono Indarto ${ }^{2}$, Diffah Hanim ${ }^{3}$ \\ ${ }^{1}$ Master Program of Nutrition Sciences Sebelas Maret University, Surakarta, Indonesia \\ ${ }^{2,3}$ Postgraduate Program of Nutrition Sciences Sebelas Maret University, Surakarta, Indonesia \\ ${ }^{2}$ Department of Physiology, Faculty of Medicine, Sebelas Maret University, Surakarta, Indonesia \\ ${ }^{2}$ Biomedical Laboratory, Faculty of Medicine, Sebelas Maret University, Surakarta, Indonesia \\ ${ }^{3}$ Department of Nutrition Sciences Sebelas Maret University, Surakarta, Indonesia \\ *E-mail: dinarp22@gmail.com
}

\begin{abstract}
Nutritional problem that occurs in adolescents due to higher food intake and less physical activity leads to overnutrition. Other nutritional problems occur among them is micronutrient deficiency including anemia, mostly in female adolescents. Higher consumption of energy-dense snacks, low physical activity and more pocket money have contributed to adolescent's body weight. This study aims to determine the correlation of frequency of snacking, hemoglobin levels, physical activity, and pocket money with the nutritional status of female adolescents. This crosssectional study was carried out in 117 female adolescents in Karanganyar Regency, Central Java Province. Data of snacking frequency was collected using the Food Frequency Questionnaire (FFQ) and hemoglobin level were measured using a Hematology Analyzer. Physical activity data were collected using the IPAQ questionnaire (International Physical Activity Questionnaire) and were converted to Metabolic Equivalent Tasks (METs). Normally distributed data then analyzed using Pearson test and Spearman test for not normally distributed data to determine correlation between independent with dependent variables and followed by the multiple linear regression test if the p-value $<0.25$. Most female adolescents had normal nutritional status, but $6.8 \%$ and $17.9 \%$ female adolescents were overweight and obesity, respectively. The frequency of snacking $(r=0.207, p=0.025)$, physical activity $(r=-0.201, p=0.030)$, pocket money $(r=0.283, p=0.002)$ and hemoglobin level $(r=0.150, p=0.107)$ were not correlated with nutritional status. In conclusion, frequency of snacks, physical activity, and pocket money were significantly correlated with nutritional status in female adolescents but no correlation with hemoglobin level.
\end{abstract}

Keywords: snacking frequency, hemoglobin, physical activity, pocket money, nutritional status.

\section{INTRODUCTION}

Adolescence is an important period for better generation which is primarily influenced by environmental factors (Bengtsson et al., 2009). Body composition, eating behavior such as eating pattern and habits, physical activity, and psychology significantly change during adolescent life (Alberga et al., 2012). Therefore, it is not surprising that nutritional problems arise in this age period (Deren et al., 2018). Malnutrition is a complex health problem that covers under and over-nutrition (WHO, 2014). Malnutrition can occur due to inadequate intake or excess energy. Malnutrition due to higher intake can lead to obesity and other comorbidities, while malnutrition due to insufficient intake can lead to stunting, wasting and deficiency of micronutrients (anemia) (Singh, 2020). Nutritional problems can occur in all ages, but female adolescences are more vulnerable than male adolescences (Alberga et al., 2012; Branca et al., 2015). Globally, the prevalence of underweight in female adolescents has slightly increased from $32 \%$ in 2005 to $36 \%$ in 2015 (Berhe et al., 2019). In Indonesia, the prevalence of wasting has decreased at the age of $13-15$ years $(11.1 \%$ to $8.7 \%$ ) and $9.4 \%$ to $8.1 \%$ (age of 16-18 years) (Indonesia Ministry of Health, 2018; Indonesia Ministry of Health, 2013) while the prevalence of wasting at the same age group in Central Java is $8.4 \%$ and $9.7 \%$, respectively (Indonesia Ministry of Health, 2018). Despite this reduction, undernutrition is still a problem because of several factors such as low consumption of fruits and vegetables, increased anemia and low physical activity. 
Many factors contribute to overweight and obesity such as higher consumption of energydense snacks and low physical activity (Al-hazzaa et al., 2014; Daly et al., 2017). Individually, some teenagers prefer snacks that look good with high calories or are energy dense and savory (De Cock et al., 2016; Hennegan et al., 2013). In addition, snacks are packaged foods that have less nutrients, are high in sodium, sugar and fat such as chiki, packaged biscuits and chips (Duffey et al., 2013; O'Connor et al., 2015).

Pocket money also affects over- nutrition because a teenager has many choices to buy snacks or fast food (Wijayanti et al., 2019; Punitha et al., 2014). Low physical activity also affects the nutritional status of adolescents because adolescents generally spend their free time doing light activities without expending a lot of energy, among others, watching movies, television, playing games and social media with gadgets (Cassidy et al., 2017; Chapman et al., 2014) thus leading to overweight and obesity (Wiklund, 2016).

Consumption of snacks that are more energy dense and high fat are often related to over nutrition (Duffey et al., 2013). Research by Bo et al. (2014) that a person who consumes 3 times or more snacks with high calories has higher BMI. Adolescents who consume snacks have 5 times greater effect on over-nutrition (Al Rahmad, 2019). This is also influenced by the allowance that is owned by the opportunity to buy food in large quantities, i.e., children with higher pocket money have a 2.18 to have a higher nutritional status (Wicaksana et al., 2019). This food intake must be balanced with adequate physical activity. Compared to sufficient physical activity, adolescents with light or insufficient physical activity has 3.3 times risk of over-nutrition (Wahyuningsih and Pratiwi 2019).

Apart from under and over-nutrition, anemia is also one of nutritional problem that often occurs in female adolescences and is generally caused by iron deficiency (Maakaron, 2019; WHO, 2011). One study reported that $60 \%$ young women in India with low hemoglobin levels have underweight (Siddharam et al., 2011). Meanwhile, in Indonesia, a research by Nisa et al. (2019) in female adolescents found a lower mean hemoglobin levels in the obese group $(12,52 \pm$ $1,34 \mathrm{~g} / \mathrm{dl}$ ) than in the normal nutritional status group $(12,62 \pm 1,48 \mathrm{~g} / \mathrm{dl})$. The purpose of this study was to determine correlation of hemoglobin levels, frequency of snacking, pocket money and physical activity with nutritional status in female adolescents.

\section{METHODS}

Female adolescents from 10th-11th grade of six high and vocational schools in Karanganyar Regency participated in this cross-sectional study. Sample size was calculated using the Slovin formula (1960) in Amirin (2011) and using the population in Karanganyar, Central Java namely

14.308 female adolescents then using purposive sampling method, we selected 117 female adolescents who met the inclusion criteria: aged 15-18 years old, were not menstruation during blood collection, and living in Karanganyar Regency in the last 6 months. Respondents agreed to take part in this study after signing the informed consent with their parents and the research protocol was approved by the Health Research Ethics Committee Faculty of Medicine, Universitas Sebelas Maret No.033 / UN27.06.6.1 / KEPK / EC/ 2020.

Data of snacking frequency were collected using the Food Frequency Questionnaire (FFQ) according to Sirajuddin et al. (2018) with a score of 50 (>3 times / day), 25 ( 1 times / day), 15

(3-6 times / week), 10 (1-2 times / week), 5 (2 times / month), 0 (never) through direct interviews by asking $>30$ types of snacks packaged such as chiki, biscuits and several other packaged snacks commonly consumed by female adolescents during the past one month, and then the total score was calculated. Categorization was done using the normality test; often (>mean) and rarely $(<$ mean). Blood hemoglobin levels were measured using the cyanmethemoglobin method with a Hematology analyzer at the Surakarta Regional Health Laboratory and the nearest Laboratory of Primary Health Centers from each district. Assessment of physical activity used the IPAQ short form to measure METs per minutes. Physical activity was then classified in to mild ( $<600 \mathrm{METs} /$ week), moderate (600-1500 METs /week) and vigorous (>1500 METs/week) categories (IPAQ, 2002). Furthermore, nutritional status was determine 
by calculating body mass index for age z-score (BAZ), which was obtained from weight and height data. Height was measured using a microtoise tool with an accuracy of $0.1 \mathrm{~cm}$ and body weight was measured using a digital scale with an accuracy of $0.1 \mathrm{~kg}$. The data then categorized as undernourished (underweight) ( $-3 \mathrm{SD}$ to $<-2 \mathrm{SD})$, normal ( $-2 \mathrm{SD}$ to $1 \mathrm{SD})$, overweight ( $>1 \mathrm{SD}$ to $2 \mathrm{SD})$, and obesity (>2 SD) (Indonesia Ministry of Health, 2020).

Statistical package for social science software (SPSS) version 21 was used to analyze all data collected from questionnaires, blood samples and anthropometric measurements. Numerical data were presented as mean $\pm \mathrm{SD}$ and categorical data were used as frequency and percentage.
For normally distributed data that is snacking frequency, Pearson test was used, while Spearman test was used for not normally distributed data including physical activity, pocket and hemoglobin levels. Then the multiple linear regression test if the p-value $<0.25$ or 0.250 . The statistical analysis was considered significance with the $\mathrm{p}$-value $<0.05$.

\section{RESULTS AND DISCUSSION}

Table 1 showed the general characteristics of respondents, which include age, parents' education, parents' income, pocket money and nutritional status. The majority of respondents were 15-16

Table 1. General Characteristics of female adolescents who participated in this study

\begin{tabular}{|c|c|c|}
\hline Variable & Mean \pm SD & $n(\%)(N=117)$ \\
\hline \multicolumn{3}{|l|}{ Age (years) } \\
\hline 15 & & $47(40.2)$ \\
\hline 16 & $15.89 \pm 0.90$ & $42(35.9)$ \\
\hline 17 & & $21(17.9)$ \\
\hline 18 & & $7(6)$ \\
\hline \multicolumn{3}{|l|}{ Father education } \\
\hline Elementary school & & $31(25.5)$ \\
\hline Junior high school & - & $35(29.9)$ \\
\hline Senior School/vocational & & $45(38.5)$ \\
\hline College & & $6(5.1)$ \\
\hline \multicolumn{3}{|l|}{ Mother education } \\
\hline Elementary school & & $38(32.5)$ \\
\hline Junior high school & - & $36(30.8)$ \\
\hline Senior School/vocational & & $37(31.6)$ \\
\hline College & & $6(5.1)$ \\
\hline \multicolumn{3}{|l|}{ Parent income (million IDR) } \\
\hline < MRW (1.989 million IDR) & $2.22 \pm 2.11$ & $63(53.8)$ \\
\hline$\geq$ MRW (1.989 million IDR) & & $54(46.2)$ \\
\hline \multicolumn{3}{|l|}{ Snacking frequency } \\
\hline Rarely $(<$ mean $)$ & $76.19 \pm 25.45$ & $54(46.2)$ \\
\hline Often $(>$ mean $)$ & & $63(53.8)$ \\
\hline \multicolumn{3}{|l|}{ Hb Levels (g/dl) } \\
\hline Anemic $(<12 \mathrm{~g} / \mathrm{dL})$ & $13.10 \pm 1.45$ & $20(17.1)$ \\
\hline Non-Anemic $(\geq 12 \mathrm{~g} / \mathrm{dL})$ & & $97(82.9)$ \\
\hline \multicolumn{3}{|l|}{ Physical activity (METs) } \\
\hline Low $(<600$ METs $)$ & $82017+20745$ & $34(29.1)$ \\
\hline Medium (600-2999 METs) & $822.4 / \pm 30 / .45$ & $80(68.4)$ \\
\hline High (>3000 METs) & & $3(2.6)$ \\
\hline \multicolumn{3}{|l|}{ Pocket money } \\
\hline$<10,000$ IDR & $11897 \pm 5728$ & $26(22.2)$ \\
\hline$\geq 10,000 \mathrm{IDR}$ & & $91(77.8)$ \\
\hline \multicolumn{3}{|l|}{ BMI/age } \\
\hline Underweight $(-3 \mathrm{SD}$ to $<-2 \mathrm{SD})$ & & $2(1.7)$ \\
\hline Normal (-2 SD to +1 SD) & - & $86(73.5)$ \\
\hline Overweight (+1 SD to $+2 \mathrm{SD})$ & & $21(17.9)$ \\
\hline Obese $(>+2 \mathrm{SD})$ & & $8(6.8)$ \\
\hline
\end{tabular}


years old with the average age of $15.89 \pm 0.903$ years old. Most parents of respondents were completed their education at high school or less. Parents earned money below the minimum regional wage (MRW) were slightly higher than that of above the MRW. Although the average of parent income was lower than the Karanganyar MRW, $77.8 \%$ respondents had more than 10,000 IDR pocket money/day. From the BMI for age variable, there were $17.9 \%$ respondents with overweight and $6.8 \%$ respondents with obese.

This result is higher than the national prevalence of overweight $(9.5 \%)$ and obesity, which is $4 \%$ (Indonesia Ministry of Health, 2018). Obesity can occur because energy intake is more than energy expenditure.

According to Huang et al. (2013) being overweight is caused by excess energy intake, inadequate physical activity, unhealthy eating patterns, or a combination of all three that results in excess energy.

This is in line with the frequency of snack consumption among adolescents that more than $50 \%$ of respondents often consume them. Respondents have physical activity that is less-moderate, while most respondents have hemoglobin levels that are classified as normal.

The classification of parents' income is based on the Regional Minimum Wage (RMW) in Karanganyar Regency (IDR 1.989.000). More than half of the respondent's parents' income is less than the RMW (53.8\%). Parental income can

Table 2. Bivariate Analysis Frequency of Snacks, Hemoglobin Levels, Physical Activity, Pocket Money and Confounding Factors with Nutritional Status

\begin{tabular}{ccc}
\hline Variable & $\mathbf{r}$ & p value \\
\hline Independent variable & & \\
Snacking frequency & 0.207 & $0.025^{*}$ \\
Hemoglobin Level & 0.150 & 0.107 \\
Physical Activity & -0.201 & 0.030 \\
Pocket Money & 0.283 & 0.002 \\
Confounding factors & & \\
Father Education & -0.036 & 0.703 \\
Mother Education & 0.22 & 0.811 \\
Parent income & -0.017 & 0.859 \\
\hline
\end{tabular}

*Pearson test, $\mathrm{p}<0.05$ significance
Table 3. Multivariate Analysis Frequency of Snacks, Hemoglobin Levels, Physical Activity, and Pocket Money with Nutritional Status

\begin{tabular}{lcccc}
\hline \multicolumn{1}{c}{ Variable } & $\mathbf{b}^{*}$ & $\mathbf{t}$ & $\mathbf{s i g}$ & $\boldsymbol{\beta}^{* *}$ \\
\hline Snacks & 0.10 & -1.831 & 0.021 & 0.204 \\
Hemoglobin Level & 0.118 & 1.620 & 0.108 & 0.142 \\
Physical Activity & -0.001 & -2.513 & 0.013 & -0.220 \\
Pocket Money & 4.351 & 2.359 & 0.020 & 0.207 \\
R square=0.145 & $\mathrm{F}=4.757$ & $p(\mathrm{sig})=0.000$ \\
\hline n observations = 117 & & & \\
$\mathrm{b} *=$ Unstandardized coefficients & & & \\
$\beta$ & & &
\end{tabular}

refer to major changes in diet and availability of food for the family (Kant and Graubard 2013).

According to Mayen et al. (2014), reported that more fat consumption compared to fiber found in higher socioeconomic groups. This is because the level of prosperity and the existence of supermarkets also affects the ability to buy food and snacks (Popkin et al., 2012). A high economy or income allows for access to purchase and consumption of energy-dense food in large quantities (Mayen et al. 2014).

The results of the correlation test used Pearson analysis showing a positive correlation between the snacking frequency and nutritional status $(r=$ 0.207, $\mathrm{p}=0.025$ ).

This research is in line with Larson et al. (2016), reported that there was a correlation between snack consumption with nutritional status. The consumption of these snacks such as chiki, potato chips, cassava chips, etc has a higher amount of energy than consumption of fruits and vegetables. In the United States, approximately $20-27 \%$ of $\mathrm{kcal} /$ day of total energy obtained from snacking and more than $27 \%$ of daily calories were from snacks (Duffey et al., 2013). The results of research by Borradaile et al. (2009) revealed that students buying food at supermarkets near schools can contribute an average of 356 additional calories and if this is done every day it will have an impact on weight gain.

Hemoglobin levels and nutritional status did not show a significant correlation $(r=0.150, p=$ 0.107) in line to the study of Parasdia et al. (2017). According to Ghrayeb et al. (2020), anemia can also cause malnutrition due to decreased appetite. Patients with iron deficiency anemia have low 
iron stores and have high leptin levels so they have a feeling of fullness and have a low appetite. Previous studies have shown that low levels of ghrelin are found in someone with low Hb levels which causes decreased appetite (Akarsu et al., 2007).

Our study reveals an inverse correlation between physical activity and nutritional status ( $\mathrm{r}$ $=-0.201, \mathrm{p}=0.030$ ), which means that the lower the physical activity, the higher the nutritional status will be. The results showed that most of the young women had moderate activity and almost half of them had light activity. According to Dapare et al. (2017) study in Ghana, there was a relationship between physical activity and nutritional status as well. Reduced physical activity can contribute to the prevalence of over-nutrition in female adolescents. The research of Grygiel-Gorniak et al. (2016) using the IPAQ questionnaire showed that adolescents with excessive food intake and high physical activity had normal nutritional status because physical activity can help burning the calories.

There was a positive correlation between pocket money and the nutritional status of female adolescents $(r=0.283, p=0.002)$ and more than $50 \%$ the adolescents got $\geq$ IDR 10,000 . Similar to Hassan et al. (2016) study in Libya, there was a positive correlation between pocket money with nutritional status in children $(\mathrm{r}=0.222 ; \mathrm{p}$ $<0.05)$. The more frequent for buying food in large quantities with low fiber content can lead to higher BMI (Akbar et al., 2015). According to Li et al. (2017), students with higher amount of pocket money have the greater ability to buy food and snacks. Therefore, they have a chance to eat excessive food and becoming overweight or obesity.

Based on our findings, parents' education and their income had no significant correlation with nutritional status in female adolescents. Other study also states that there was no relationship the education of the father and mother with the nutritional status of children because education cannot be used as a benchmark that higher education means that knowledge in all fields is also good. Parents' interest in seeking information from various sources can be linked to good nutritional knowledge (Putri et al., 2017). Other research have reported that mothers with higher education provide nutritional and healthy foods for optimum growth of their children, compared to mothers with lower education (Victora et al. 2008; Lopez et al. 2012; Vollmer et al., 2017); also emphasized that mother's education has a more effect on the children health and nutritional status because mothers play an important role for providing their daily food intake, especially for their children.

Then this insignificant, according to the study of Susanti et al. (2012) stated that parents' income is not slightly dependent on the influence of nutritional status in the sense that even though they have low income, children are always given food with adequate nutritional value even though the price is cheap. This is in line with research which states that most of the respondents earn

$<$ MRW, but more than $50 \%$ of female adolescent have normal nutritional status. In contrast to our study, Suhartini and Ahmad (2018) reported that parent income has a correlation with nutritional status $(p=0.037)$ in adolescents. Study to Shariff et al. (2015) conducted in Malaysia explained that low socioeconomic status as indicated by low parent income could limit access to adequate diets thus could affect nutritional status.

From data of multiple linear regression test, significant correlations were observed from the independent variables and nutritional status except hemoglobin levels ( $p=0.108, b=0.118)$, because most female adolescents $(82.9 \%)$ had normal hemoglobin levels. Study by Indartanti and Kartini (2014) also reports that there is no relationship between those two $(p>0.005)$. This is because most female adolescents had normal nutritional status and hemoglobin levels. Anemia tends to be deficient in micronutrients $(\mathrm{Fe})$ so that it does not affect nutritional status based on BMI/age because it has a low energy content, and if deficiency occurs it can last a long time (Rosmalina and Ernawati, 2010)

In addition, all variables contributed to $14.5 \%$ nutritional status of female adolescents. It clearly indicated that many factors importantly influence nutritional status in female adolescents such as macronutrient intake. The limitation of our study is that we did not calculate the number of nutritional snacks, daily food intake consumed, and records of female adolescent pocket money expenditures. 


\section{CONCLUSION}

Frequency of snacks, physical activity, and pocket money significantly correlate with nutritional status in female adolescents but no correlation for hemoglobin level. In order to prevent obesity in female adolescents, those factors should be socialized by determinants of nutrition policies related to health for female adolescent, counseling on adolescent nutritional status and healthy lifestyles to students.

\section{REFERENCE}

Akarsu, S., Ustundag, B., Gurgoze, M.K., Sen, Y., \& Aygun, A. D. (2007). Plasma ghrelin levels in various stages of development of iron deficiency anemia. Journal of pediatric hematology/oncology, 29 (6): 384-87. doi: 10.1097/MPH.0b013e3180645170.

Akbar, F. N., Lodhi, A., Mahmood, S., Mueen-udDin, G., \& Murtaza, M. A. (2015). Nutritional status of school going children in relation to their dietary intake at mid-morning. Pakistan Journal of Nutrition 14 (3): 150-54. doi: 10.3923/ pjn.2015.150.154.

Al Rahmad, A. H. (2019). Keterkaitan asupan makanan dan sedentari dengan kejadian obesitas pada anak sekolah dasar di Kota Banda Aceh. Buletin Penelitian Kesehatan 47 (1): 67-76. doi: 10.22435/bpk.v47i1.579.

Al-hazzaa, H. M., Abahussain, N. A., Al-sobayel, H. I., Qahwaji, D. M., Alsulaiman, N. A., \& Musaiger, A. O.. (2014). Prevalence of overweight, obesity, and abdominal obesity among urban saudi adolescents : gender and regional variations. J Health Popul Nutr. 32 (4): 634-45. Retrieved fromhttps://www.ncbi.nlm. nih.gov/pmc/articles/PMC4438694/

Alberga, A. S., Sigal, R. J., Goldfield, G., Prud Homme, D., \& Kenny, G. P. (2012). Overweight and obese teenagers: why is adolescence a critical period?. Pediatric Obesity 7 (4): 261-73. doi: 10.1111/j.20476310.2011.00046.x.

Bedahan 02 Cibinong Kabupaten Bogor Tahun 2018. Jurnal Ilmiah Kesehatan Masyarakat 11

: 35-48. Retrieved from https://jikm.upnvj. ac.id/ index.php/home/article/view/13.

Bengtsson, Tommy, \& Geraldine, P., Mineau. (2009). Early-life effects on socio-economic performance and mortality in later life: a full life-course approach using contemporary and historical sources. Social Science
andMedicine 68 (9): 1561-64. doi: 10.1016/j. socscimed.2009.02.012

Berhe, K., Kidanemariam, A., Gebremariam, G, \& Gebremariam, A. ( 2019). Prevalence and associated factors of adolescent undernutrition in ethiopia: a systematic review and metaanalysis. BMC Infectious Diseases 5 (49): 1-13. doi: 10.1186/s40795-019-0309-4.

Bo, S., Carli, L. D, Venco, E., Fanzola, I., Maiandi, M., De Michieli, F., Durazzo, M., Beccuti G., \& Cavallo-perin, P. (2014). Impact of snacking pattern on overweight and obesity risk in a cohort of 11- to 13-year-old adolescents. Journal of Pediatric Gastroenterology \& Nutrition 59 (4): 465-71. doi:10.1097/ MPG.0000000000000453.

Borradaile, K. E., Sherman, S., Veur, S. S. V., McCoy, T., Sandoval, B., Nachmani, J., Karpyn, A., \& Foster, G. D. (2009). Snacking in children: the role of urban corner stores.Pediatrics 124 (5): 1293-98. doi: 10.1542/peds.2009-0964.

Branca, F., Piwoz, E., Schultink, W., \& Sullivan, L. A. (2015). Nutrition and health in women, children, and adolescent girls. British Medical Journal 351 (November): 27-31. doi: 10.1136/ bmj.h4173.

Cassidy, S., Chau, J. Y., Catt, M., Bauman, A., \& Trenell, M. I. (2017). Low physical activity, high television viewing and poor sleep duration cluster in overweight and obese adults; a crosssectional study of 398,984 participants from The UK Biobank. International Journal of Behavioral Nutrition and Physical Activity 14 (1): 1-10. doi: 10.1186/s12966-017-0514-y.

Chapman, C. D., Nilsson, V. C., Thune, H. A., Cedernaes, J., Le Grevès, M., Hogenkamp, P. S., Benedict, C, \& Schioth, H. B. (2014). Watching TV and Food Intake: The Role of Content. PLOS ONE 9 (7): 7-10. doi: 10.1371/ journal. pone.0100602.

Cock, N. D., Lippevelde, W. V., Vervoort, L., Vangeel, L., Maes, L., Eggermont, S., Braet, C., et al. (2016). Sensitivity to reward is associated with snack and sugar-sweetened beverage consumption in adolescents. European Journal of Nutrition 55 (4): 1623-32. doi: 10.1007/ s00394-015-0981-3.

Daly, C. M., Foote, S. J., \& Wadsworth, D. D. (2017). Physical activity, sedentary behavior, fruit and vegetable consumption and access: what influences obesity in rural children? Journal of Community Health 42 (5): 968-73. DOI: 10.1007/s10900-017-0343-6. 
Dapare, P. P. M., Adams, Y., Djabuni, E. K., Osei, I., \& Shittu, S. O. (2017). Nutrient intake, physical activity and nutritional status among second cycle students in Tamale, Ghana. Journal of Medical and Biomedical Science 6 (2): 25-37. doi: $10.4314 /$ jmbs.v6i2.4.

Deren, K., Nyankovskyy, S., Nyankovska, O., Łuszczki, E., Wyszynska, J., Sobolewski, M., \& Mazur, A. (2018). The prevalence of underweight, overweight and obesity in children and adolescents from Ukraine."Scientific Reports 8 (1): 1-7. doi: 10.1038/s41598-01821773-4.

Duffey, Kiyah, J., Pereira, R. A., \& Popkin, B.M. (2013). Prevalence and energy intake from snacking in brazil: analysis of the first nationwide individual survey. European Journal of Clinical Nutrition 67 (8): 868-74. doi: 10.1038/ejen.2013.60.

Ghrayeb, H., Elias, M., Nashashibi, J., Youssef, A., Manal, M., Mahagna, L., Refaat, M., Schwartz, N., \& Elias., A. (2020). Appetite and ghrelin levels in iron deficiency anemia and the effect of parenteral iron therapy : a longitudinal study. PloS one, 15 (6): 1-14. doi:10.1371/journal. pone. 0234209 .

Grygiel-Gorniak, B., Tomczak A., Krulikowska, N., Przysławski, J., Seraszek-Jaros, A., \& Elzbieta,

K. (2016). Physical activity, nutritional status, and dietary habits of students of a medical university. Sport Sciences for Health 12 (2): 261-67. doi: 10.1007/s11332-016-0285-x.

Hassan, E. M., Hashad, L. A. K., \& Hassan, M. I. (2016). Nutritional status of school children in Tripoli City, Libya 2012. Journal of Food and Nutrition Research 4 (4): 223-29. doi:10.12691/ jfnr-4-4-5.

Hennegan, Julie, M., Natalie, J., Loxton, \& Mattar A. (2013). Great expectations. eating expectancies as mediators of reinforcement sensitivity and eating. Appetite 71: 81-88. doi:10.1016/j.appet.2013.07.013.

Huang, J. S., Barlow, S. E., Quiros-Tejeira R. E., Scheimann, A., Skelton, J., Suskind, D., ... Xanthakos, S. A. (2013). Childhood obesity for pediatric gastroenterologists. Journal of Pediatric Gastroenterology and Nutrition 56 (1): 99-109. doi: 10.1097/ MPG.0b013e31826d3c62.

Kant, A. K.., \& Graubard, B. I. (2013). Family income and education were related with 30 - year time trends in dietary and meal behaviors of American children and adolescents. Journal of Nutrition 143 (5): 690-700. doi: 10.3945/ jn.112.165258.

Kementerian Kesehatan Republik Indonesia Tahun 2020. (2020). Standar Antropometri Anak. Jakarta: Kementerian Kesehatan RI..

Kementerian Kesehatan Republik Indonesia. (2013). Riset Kesehatan Dasar Indonesia Tahun 2013. Jakarta.

Kementerian Kesehatan. (2018). Riset Kesehatan Dasar Indonesia Tahun 2018. Jakarta: Badan Penelitian dan Pengembangan Kesehatan, Kementerian Kesehatan RI.

Larson, N. I., Miller, J.M., Watts, A. W., Story, M. T., \& Neumark-Sztainer, D. R. (2016). Adolescent snacking behaviors are associated with dietary intake and weight status. Journal of Nutrition 146 (7): 1348-55. doi: 10.3945/ jn.116.230334.

Li, M., Xue, H., Jia, P., Zhao, Y., Wang, Z., Xu, F., \& Wang, Y. (2017). Pocket money, eating behaviors, and weight status among chinese children: the childhood obesity study in China Mega-Cities. Preventive Medicine 100 (April): 208-15. doi: 10.1016/j.ypmed.2017.04.031.

Lopez, P. M., Karim, A., Mohamed, C., Abdellatif, B., \& Lopez, S. R. (2012). Nutritional status of adolescents in the context of the moroccan nutritional transition: the role of parental education. Journal of Biosocial Science 44 (4): 481-94. doi: 10.1017/s0021932011000757.

Maakaron, J.E. (2019). Anemia: Practice Essentials, Pathophysiology, Etiology. Medscape.

Mayen, A. L., Marques-Vidal, P., Paccaud, F., Bovet, P., \& Stringhini, S. (2014). Socioeconomic determinants of dietary patterns in low- and middle-income countries: a systematic review. American Journal of Clinical Nutrition 100 (6): 1520-31. doi: 10.3945/ajen.114.089029.

Nisa, Ana, K., Nissa C., \& Probosari N. (2019). "Perbedaan asupan gizi dan kadar hemoglobin pada remaja perempuan obesitas dan tidak obesitas. Journal of Nutrition College 8 (1): 21-28. doi: 10.14710/jnc.v8i1.23809.

Parasdia, R. A., Sari, P., Ari, I. S., \& Widjayanti, M. (2017). Hubungan anemia dengan status gizi pada remaja putri. The Southeast Asian Journal of Midwifery 3 (2): 27-32. doi: 10.36749/ seajom.v3i2.11.

Popkin, B. M., Adair, L. S., \& Shu, W. G. (2012). The global nutrition transition: the pandemic of 
obesity in developing countries. Nutrients 58 (1): 1-10. doi: 10.1111/j.1753-4887.2011.00456.x.

Punitha, V.C., Amudhan, A., Sivaprakasam, P., \& Rathnaprabhu, V. (2014). Pocket money: influence on body mass index and dental caries among urban adolescents. Journal of Clinical and Diagnostic Research 8 (12): JC10-12. doi: 10.7860/JCDR/2014/10498.5310.

Putri, R. M.,.Wahidyanti, R. H., \& Maemunah,

N. (2017). Kaitan pendidikan, pekerjaan orang tua dengan status gizi anak pra sekolah. Care : Jurnal Ilmiah Ilmu Kesehatan 5 (2): 231-45. Retrieved from https://jurnal.unitri.ac.id/index. $\mathrm{php} / \mathrm{care} /$ article/view/841.

Shariff, Z. M., Lin, K. G., Sariman, S., Lee, H.S., Siew, C. Y., Nisak, B., \& Yusof, M.. (2015). The relationship between household income and dietary intakes of 1-10 year old urban Malaysian. Nutrition Research and Practice 9 (3): 278-87. doi: 10.4162/nrp.2015.9.3.278.

Siddharam, S. M., Venketesh, G. M., \& Thejeshwari,

H. L. (2011). A study of anemia among adolescent girls in rural area of Hassan District

, Karnataka, South India . Lnt J Biol Med Res 2 (4): 922-24. Retrieved from https://citeseerx. ist. psu.edu/viewdoc/download?doi=10.1.1.302

$.7602 \&$ rep $=$ rep $1 \&$ type $=$ pdf.

Singh, A. (2020). Childhood Malnutrition in India. Perspective of Recent Advances in Acute Diarrhea. doi:10.5772/intechopen.89701.

Sirajuddin, Surmita, \& Trina Astuti. 2018. Survey Konsumsi Pangan. Jakarta.

Suhartini \& Ahmad. 2018. Analisis faktor yang berhubungan dengan status gizi remaja putri pada siswi kelas VII SMPN 2 Desa Tambak Baya Kecamatan Cibadak Kabupaten Lebak Tahun 2017. Jurnal Medikes (Media Informasi Kesehatan) 5 (1): 72-82. doi: 10.36743/ medikes.v5i1.48.
Victora, C. G., Adair, L., Fall, C., Hallal, P. C., Martorell, R., Richter, L., \& Sachdev, H.S. (2008). Maternal and child undernutrition: consequences for adult health and human capital. The Lancet 371 (9609): 340-57. doi: 10.1016/ S0140-6736(07)61692-4.

Vollmer, S., Bommer, C., Krishna, A., Harttgen, K., \& Subramanian, S. V. (2017). The association of parental education with childhood undernutrition in low- and middle-income countries: comparing the role of paternal and maternal education. International Journal of Epidemiology 46 (1): 312-23. doi: 10.1093/ije/dyw133.

WHO. (2011). Haemoglobin concentrations for the diagnosis of anaemia and assessment of severity. In Worl Health Organization, Vitamin and Mineral Nutrition Information System, 1-6. Geneva, Switzerland: WHO.

WHO. (2014). Global Nutrition Targets 2025 Anaemia Policy Brief. Geneva: WHO.

Wahyuningsih, R., \& Pratiwi, I. G. (2019). Hubungan aktifitas fisik dengan kejadian kegemukan pada remaja di Jurusan Gizi Politeknik Kesehatan Mataram. AcTion: Aceh Nutrition Journal, 4 (2): 163. doi: $10.30867 /$ action.v4i2.180.

Wicaksana, D. A., \& Nurrizka, R. H., (2019). Faktor-faktor yang berhubungan dengan status gizi pada anak usia sekolah di SDN

Wijayanti, D., Salimo, H., \& Dewi, Y. L. R. (2019). Multilevel analysis on the determinants of overweight and obesity among primary school students in Boyolali, Central Java. Journal of Maternal and Child Health 4 (5): 294-301. doi:10.26911/thejmch.2019.04.05.01.

Wiklund, P. (2016). The role of physical activity and exercise in obesity and weight management: time for critical appraisal. Journal of Sport and Health Science 5 (2): 151-54. doi:10.1016/j. jshs.2016.04.001 